\title{
Influence of School Characteristics on Students' Discipline in Public Secondary Schools in Machakos County, Kenya
}

\author{
Caroline Kulu Ngao \& Martin Ogola \\ ${ }^{1}$ Post Graduate Scholar, ${ }^{2}$ Professor \\ Department of Educational Management Policy and Curriculum Studies
}

Kenyatta University

Carolinengao9@gmail.com

\begin{abstract}
The study sought to find out the influence of school characteristics on the discipline of schools in Machakos County. The study adopted a correlational research design. The target population was the 153 secondary schools in Machakos County. The research used stratified sampling, random sampling and purposive sampling methods to determine the sample size. The study had a sample size of 231 respondents of which 168 were students, 21 principals and 42 teachers. Interview guides and questionnaires were used for data collection. The study revealed that there was a strong positive relationship between guidance and counselling approaches and school discipline $(r=0.615$, $p$-value <0.05), and also a significant positive relationship between school type and discipline $(r=0.773$, p-value $<0.05)$. The study recommended that secondary school administration should enhance identifying and addressing all forms of indiscipline especially vernacular speaking which was observed to be a way of including some learners while excluding others when planning acts of indiscipline.
\end{abstract}

Keywords: Guidance and Counseling Approaches, Students' Council, School Administration, School Type.

\section{INTRODUCTION}

Discipline is essential for smooth functioning of schools and society. It is an important component of human behaviour which not only helps to regulate people's reactions to various situations but also their relations with others. Thus, the effectiveness of any organization is largely affected by the level of discipline of its members. All social organizations have rules governing their procedures, which act as an overall framework that regulates behaviour declared appropriate to the ongoing purpose of an organization. Mbiti (2007) defines discipline as the moral capacity or disposition which when ingrained in the human capacity, becomes a powerful habit for self-control. Discipline therefore involves the development of an informed conscience within the individual person as part of his or her personality. Jeng (2011) points out that indeed, it encompasses training of the mind and character of a person which results to self-control and a habit of obedience.

The main reason why students attend school is to receive good education. Sound education can only be provided when there is discipline in schools. Discipline is the number one topic among others in education. Jeng (2011) advises that students should understand that discipline is one of the most fundamental characteristics of a human being in school, in our homes and indeed everywhere in the world. Stakeholders concur that ensuring discipline in schools is top on the agenda because one cannot acquire knowledge without character.

The school being a social organization has norms which regulate students' behaviour as well as staff behaviour. Muriithi (2010) states that as an active processing agency, the school takes the parental role of enabling the students to gain self- discipline based on generally acceptable forms of behaviour to which they are expected to conform.

Indiscipline is the intentional refusal to follow rules and regulations of a given society. It is deeply rooted not only in Kenyan schools, but also, regionally and internationally too. According to the Task Force on Student Discipline and Unrests in Secondary Schools (Wangai report, 2001), learning institutions have been faced with increased cases of student unrests. The issue of learner indiscipline has taken center stage for a long time internationally, regionally and even locally. UNESCO (2012) notes that the number of unruly classrooms around the world has reached a very alarming proportion. According to their report, a bully in a school in Argentina wounded a thirteen-year-old pupil after he allegedly refused to give him his cell phone. In Springfield, USA, one student was reported dead and 30 wounded in a shooting associated with indiscipline, while in Kobe-Japan, a school child was 
decapitated by a fourteen year-old. Killings, physical attacks, robberies, attempted arson and fighting between children which end in tragedies have been making headlines the world over.

School violence that involves knives, baseball bats, marijuana, guns and even bombs have become common. Incidents have also been reported from Mexico, Italy, Germany, India, Comoros and even Spain (UNESCO, 2012).

Recent studies from Africa have also shown that physical fighting among school going adolescents is prevalent especially when they feel that their voices are never heard (Human Rights Watch, 2010). For example, Rukundo (2009) reported that 50.6\% of adolescents had engaged in physical fighting with their fellow students, teachers, authority or prefects within the past 12 months prior to the survey in Namibia, southern Africa. While deaths were the most severe consequences of interpersonal violence, the effects of school violence include: interference with the normal learning activities of students; weapon carrying for defensive purposes on school grounds; serious injury and increased medical costs and absenteeism from school (WHO, 2014).

Maphosa and Shumba (2010) observe that cases of learner indiscipline in South Africa are on the increase. They argue that indiscipline among the students has led to suspensions and expulsion where students have been involved in substance abuse, theft and watching pornography. Drug abuse is seen as one of the signs of growing indiscipline in schools. Students' indiscipline in secondary schools in Kenya has also been an issue of great public concern for the last few years. The subject has for long been debated and has featured repeatedly in schools, the press, as well as in the national agenda. The Government of Kenya (GOK) is currently implementing several measures aimed at curbing the various cases of indiscipline in learning institutions, particularly the use of guidance and counselling units in all secondary schools (MOEST, 2008).

Task forces on students' indiscipline and unrest in secondary schools have been formed. The Wangai Commission (Republic of Kenya, 2001) for example, recommended the introduction of guidance and counselling units in public secondary schools. Over the years, various task forces have been put in place by the government to try and unearth the factors which contribute to indiscipline in secondary schools in the country. Examples include the Sagini Taskforce of 1991 which identified lack of role models; overloaded school curriculum and communication breakdown between the students and the administration among the causes of unrest in schools.

The Macharia Taskforce of 2000 identified inadequate quantity or quality of food; attempt to change some long established school traditions; drug abuse in schools; lack of observance of professional ethics by teachers; the prefect factor; fear of examinations and poor results; school administrative styles among others. Wangai Taskforce of 2001 identified cultural conflicts filtering into the school; influence of opinion leaders at variance with the students' interests; the largely abdicated role of parents; moral decay afflicting the current generation of youths; deteriorating levels of nationalism and external school environment among others.

In spite of these efforts, there have been several cases of student indiscipline reported in the media and in studies done in this field (Kindiki, 2009; Muratha, 2013). Machakos County has also had its fair share of waves of students' unrest. Between 2014-2018, schools have engaged in one or another form of unrest. Particularly there have been instances of arson where dormitories and administration blocks have been razed down (Machakos County Education Office Report, 2018). This study therefore aimed at assessing indiscipline among secondary school students in Machakos County.

Specifically, the study aimed at answering the following questions:

i. How does guidance and counselling approaches influence students' discipline in public secondary schools in Machakos County?

ii. In what ways does the school type influence discipline in public secondary schools in Machakos County?

iii. How effective are the students' councils in maintaining students' discipline in secondary schools in Machakos County?

The following research hypotheses guided the study:

$\mathrm{HO}_{1}$ : Guidance and counselling approaches have no significant influence on students' discipline in secondary schools in Machakos County.

$\mathrm{HO}_{2}$ : School type has no significant influence on discipline in secondary schools in Machakos County.

\section{THEORETICAL FRAMEWORK}

This study was guided by Jones's management model. Jones's model classroom management training programme acknowledges that there is no single, "best" method of dealing with discipline in the classroom. Classroom situations differ and they will therefore require different approaches. This underpinning rationale opens the opportunity to combine insights from behaviourist and cognitivist approaches. Every model makes some contribution to reducing classroom disruption and increasing productivity. These models can either fail if they are abused or succeed if used appropriately. Jones (1987) suggests the use of body language and incentive system (behaviourist elements) and efficient individual help for students (cognitivist approach). 
Jones recommends that educators should structure learning in their classroom properly; they should learn how to maintain control by using appropriate instructional strategies. They should build patterns and co-operation; they should develop appropriate backup methods in the event of misbehaviour (Burden, 1995).

The theory argues that educators lose approximately 50 per cent of their instructional time attending to learners who cause disturbances in the classroom. Effective body language, incentive systems and individual help can be used to redeem the lost teaching time. He further confirms that good discipline comes from effective body language, which includes posture, eye contact, facial expressions, signal and gestures (Burden 1995). Jones (1987) holds that the body language is the language of the emotions, thus discipline is 90 per cent effective body language. He notes that most misbehaviour occurs away from the educator (Charles 2002). Educators tend to make sure that all learners who are prone to misbehave are seated in the front of the classroom. Incentive systems as one of the strategies is something outside of the individual, it makes the learner react. All educators know that wellmotivated learners tend to work more diligently at school tasks and in doing so they learn more and cause fewer disciplinary problems.

A concern about this model is the need for a long-term commitment from educators. As is the case with reality therapy, considerable time is needed. It assumes that incentives make learners behave well and this enables motivated educators to be in a position to motivate learners. Suffice it to say that techniques of handling learner misbehaviour are often seen in the most effective and motivated educators. An underlying belief of the model includes making rules that will be quickly enforced, learning and implementing Jones's body language and procedures for stopping misbehaviour. Remaining unemotional and firm in correcting behaviour and developing an incentive system are also important elements.

Applying the theory specifically to the study, dealing with indiscipline in schools should be unemotional and therefore objective. School administrators must also be able to adopt a variety of methods to deal with indiscipline as there is no 'one size fits all' solution' use of the various approaches will therefore have an effect on discipline in the schools.

\section{RESEARCH METHODOLOGY AND METHODS}

The study adopted a correlational research design. This was done through the application of inferential statistics in the form of a multiple linear regression analysis model, with guidance and counselling approaches, school type and effectiveness of students' councils as the independent variables, and discipline as the dependent variable.

The target population was all the 153 public secondary schools in Machakos County. The research used stratified sampling, purposive sampling and simple random sampling methods. Schools were stratified depending on their categories i.e. National, Extra County and County schools. Purposive sampling was used to identify the 21 schools which had experienced strikes in the County. The 21 head teachers of the selected schools were also purposively identified. Simple random sampling was used to select the teachers from each of the schools to participate in the study. Convenience sampling was used to identify 168 students. The study used a sample size of 231 comprising of 21 principals identified through purposive sampling, 42 teachers selected through simple random sampling and 168 students identified through convenience sampling. Since the target student population was 16,800 and resources and time were a major constraint, $1 \%$ sample was adopted. This gave a sample size of 168 students. The samples were selected proportionately. The sample comprised 84 boys and 84 girls. Data were collected using questionnaires and interviews. The main focus of the interview was to ascertain clarification on some of the emerging issues from the quantitative data analysis. Themes were generated from the qualitative data in accordance with the emerging issues and used to support the quantitative findings. The Statistical Package for Social Sciences computer software (version 22) was employed to generate the output in form of descriptive statistics e.g. frequency tables, means and percentages for ease of analysis. The purpose of descriptive statistics was to enable the researcher to meaningfully describe a distribution of scores or measurements using a few indices or statistics. The researcher used multiple regression analysis to establish the relationship between the independent variables and the dependent variable. The results are presented using frequency distribution tables.

\section{Ethical considerations}

These included voluntary participation and informed consent from the respondents. The researcher obtained authority to conduct research from Kenyatta University. A research permit from the National Council for Science Technology and Innovation was also obtained before the research commenced. Approval was also sought from the management of the schools where data collection was conducted. The researcher assured the respondents in the research process that the research was purely for academic purposes and that the information they provided would be treated with utmost confidentiality. An informed assent for children form was also attached to the questionnaire for participants under the age of 18 years. Respondents were further requested not to indicate their names anywhere on the questionnaires to ensure anonymity. 


\section{RESULTS}

Guidance and Counselling

The first question sought to establish the effect of guidance and counselling on discipline of schools. The study adopted the following key (Agree (A), Don't Know (DK) and Disagree (D). The findings were as shown on Table 1

Table 1: Statements on the effect of guidance and counselling on discipline

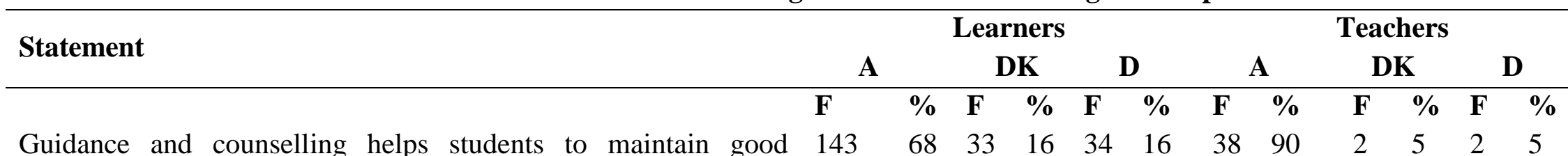

behavior at all times.

After offering counselling to students who don't obey the school $\quad \begin{array}{llllllllllll}149 & 71 & 19 & 9 & 42 & 20 & 32 & 76 & 0 & 0 & 10 & 24\end{array}$

rules, good behaviour is restored

The peer counsellors in my school serve as good role models to $\begin{array}{llllllllllll}121 & 58 & 26 & 12 & 63 & 30 & 28 & 67 & 6 & 14 & 8 & 15\end{array}$

help students to obey the school rules

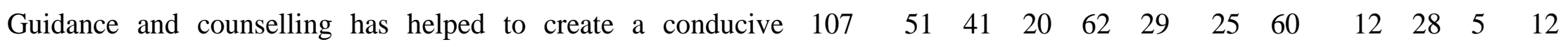

learning environment in my school.

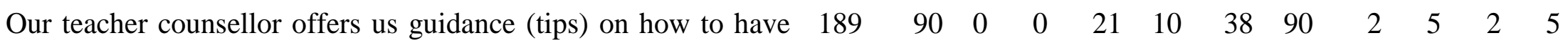

good behaviour at all times

Information on how to behave appropriately is displayed on the $\begin{array}{llllllllllll}167 & 80 & 0 & 0 & 43 & 21 & 42 & 100 & 0 & 0 & 0 & 0\end{array}$

school noticeboards

Students who break school rules are counselled to help them $\begin{array}{lllllllllllll}157 & 75 & 11 & 5 & 42 & 20 & 42 & 100 & 0 & 0 & 0 & 0\end{array}$ change behavior 
Volume 1, Issue 9, November - 2021

www.ijsar.net

Majority of the respondents (over $50 \%$ of both students and teachers) agreed that guidance and counselling had a positive influence on discipline. Guidance and counselling ensured good behaviour, creating a conducive learning environment and it was used as a source of information for appropriate school behaviour.

\section{School Type}

The second question sought to find out the influence of school type on discipline. The results were as illustrated on Figure 1

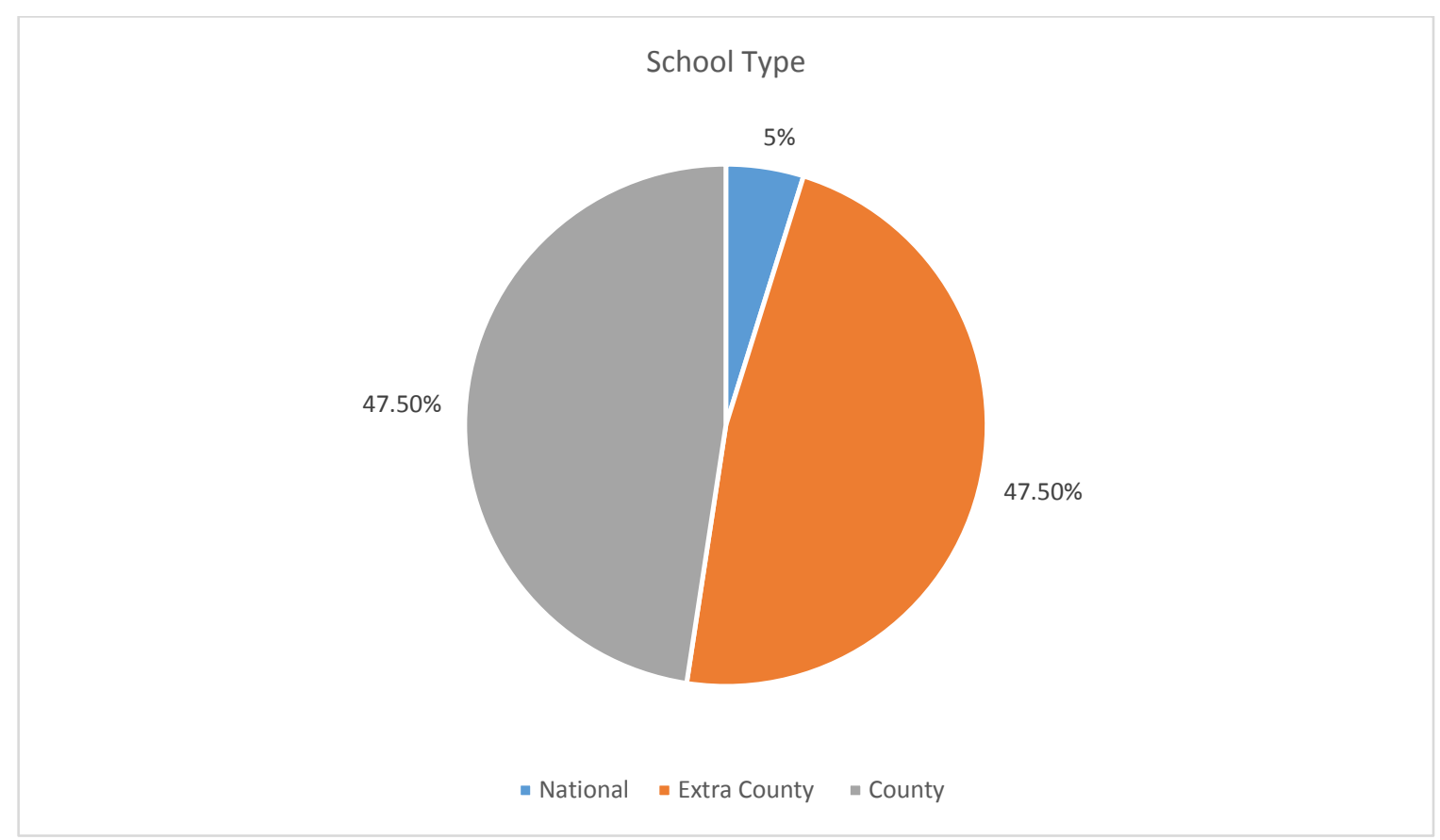

Figure 1: School Type

The findings as indicated on Figure 1 show that both county and extra county schools' categories formed $47.5 \%$ of the total schools in the study each, while the national school category formed $5 \%$ of the schools. This implied that both the extra-county and county schools formed the larger part of the study population. Nevertheless, there had been no major cases of indiscipline in the national school, and the learners had not participated in a single strike or acts of arson. This was contrary to the findings on the county and extra county schools which recorded all the cases of indiscipline including arson and drug use. 
International Journal of Scientific and Academic Research (IJSAR), Vol.1, Issue 9, November-2021

\section{Effectiveness of the Student Council}

The third question sought to establish the perceptions on the effectiveness of the students' council. The findings were as shown on Table 2.

\section{Table 2: Statements on the eeffectiveness of the Student Council}

\begin{tabular}{|c|c|c|c|c|c|c|c|c|c|c|c|c|}
\hline \multirow{3}{*}{ Statement } & \multicolumn{6}{|c|}{ Learners } & \multicolumn{6}{|c|}{ Teachers } \\
\hline & \multicolumn{2}{|c|}{$\mathbf{A}$} & \multicolumn{2}{|c|}{$\mathbf{N}$} & \multicolumn{2}{|c|}{ D } & \multicolumn{2}{|c|}{$\mathbf{A}$} & \multicolumn{2}{|r|}{$\mathbf{N}$} & \multicolumn{2}{|r|}{ D } \\
\hline & $\mathbf{F}$ & $\%$ & $\mathbf{F}$ & $\%$ & $\mathbf{F}$ & $\%$ & $\mathbf{F}$ & $\%$ & $\mathbf{F}$ & $\%$ & $\mathbf{F}$ & $\%$ \\
\hline $\begin{array}{l}\text { The student council is involved by the administration in } \\
\text { students' dispute resolution }\end{array}$ & 146 & 70 & 24 & 11 & 40 & 19 & 33 & 78 & 7 & 17 & 2 & 5 \\
\hline $\begin{array}{l}\text { The student council is always consulted when students' } \\
\text { issues are discussed by the principal and teachers. }\end{array}$ & 113 & 54 & 47 & 22 & 50 & 24 & 26 & 62 & 6 & 14 & 10 & 24 \\
\hline $\begin{array}{l}\text { The student council regularly interacts with the school } \\
\text { administration. }\end{array}$ & 73 & 35 & 44 & 21 & 93 & 44 & 18 & 42 & 9 & 21 & 15 & 37 \\
\hline $\begin{array}{l}\text { The student council effectively presents students' issues } \\
\text { and concerns }\end{array}$ & 81 & 39 & 106 & 50 & 23 & 11 & 17 & 41 & 14 & 33 & 11 & 26 \\
\hline $\begin{array}{l}\text { The student council assists in maintenance of discipline } \\
\text { among students }\end{array}$ & 117 & 56 & 47 & 22 & 46 & 22 & 22 & 52 & 7 & 17 & 13 & 31 \\
\hline $\begin{array}{l}\text { The student council works with the school } \\
\text { administration to promote a culture of learning in the } \\
\text { school. }\end{array}$ & 67 & 32 & 119 & 57 & 24 & 11 & 14 & 33 & 16 & 38 & 12 & 29 \\
\hline
\end{tabular}


Results generally indicate an agreement with the statements on the involvement of the students' councils by the school administration except in the area of whether the council effectively presents students' issues and whether the councils work with the school administration to promote a culture of learning, as reported by the students.

A null hypothesis was formulated and tested using standard multiple regression analysis to examine the influence of school characteristics on discipline. The results of the Multiple Regression are as summarized on Table 4.

Table 4 Results of the Multiple Regression

\begin{tabular}{|c|c|c|c|c|c|c|}
\hline \multirow[t]{2}{*}{ Model } & & \multicolumn{2}{|c|}{$\begin{array}{l}\text { Unstandardized } \\
\text { Coefficients }\end{array}$} & \multirow{2}{*}{$\begin{array}{l}\text { Standardized } \\
\text { Coefficients } \\
\text { Beta }\end{array}$} & \multirow[t]{2}{*}{$\mathrm{t}$} & \multirow[t]{2}{*}{ Sig. } \\
\hline & & B & Std. Error & & & \\
\hline \multirow[t]{3}{*}{1} & (Constant) & 6.182 & .826 & & 7.484 & 0.0000 \\
\hline & $\begin{array}{l}\text { Guidance and } \\
\text { Counselling }\end{array}$ & 0.567 & .234 & 0.045 & 2.423 & 0.0201 \\
\hline & School Type & 0.476 & .205 & 0.142 & 2.322 & 0.0255 \\
\hline
\end{tabular}

Since the calculated P value of .0201 was less than the level of significance of .05 , the null hypothesis that guidance and counselling approaches had no statistically significant influence on students' discipline in secondary schools in Machakos County was rejected. Consequently, the unstated alternative hypothesis that guidance and counselling approaches had a statistically significant influence on students' discipline in secondary schools in Machakos County.

Again, the calculated P value of .0205 was less than the level of significance of .05, thus the null hypothesis that school type had no statistically significant influence on students' discipline in secondary schools in Machakos County was rejected and the unstated alternative that school type had a statistically significant influence on students' discipline in secondary schools in Machakos County adopted.

Substituting the regression model $\mathrm{Y}_{\mathrm{i}}=\alpha+\beta_{1} \mathrm{X}_{1}+\beta_{2} \mathrm{X}_{2}+\varepsilon$, it becomes:

Predicted Discipline $=6.182+0.567(\mathrm{G} \& \mathrm{C})+0.476(\mathrm{ST}) \mathrm{X}_{4}+\varepsilon$

Where; G\&C = Guidance and counselling, $\mathrm{ST}=$ School type, $\varepsilon=$ error term

\section{DISCUSSION}

\section{Guidance and Counseling}

Guidance and counselling is a key process in the maintenance of school discipline. It is actually considered the fall back plan especially after the abolition of corporal punishment in public schools. These findings agree with those of (Makinde, 2014) who sees guidance as the process of helping an individual understand himself and his world while counselling is an interactive process between the counselor and the counselee where the counselee is vulnerable and needs assistance while a counselor should be trained and educated to give assistance. According to Mutie \& Ndambuki (1999) counselling develops self-knowledge, emotional acceptance and growth, and use of personal resources to assist clients to fit in the environment.

Further, Epstein, Sanders, Sheldon, Simon, Salinas, Jansorn \& Hi (2018) argue that guidance and counselling should be an integral part of the school's total educational programme where counselors work in collaboration with students, parents/families, teachers, administrators and community. Trained counselors should be placed in schools and colleges to prevent crimes and indiscipline, rehabilitate or remedy existing bad practices and formulate programme of development for good neighborliness (Mikaye, 2012). Mutie \& Ndambuki (1999) also aver that guidance programme helps to minimize the incidences of indiscipline since it gives a sense of direction, a sense of purpose and a sense of fulfillment where proper utilization of time spent outside the classroom is also enhanced. Counselling on the other hand is a very important programme since it helps the client to be helped to manage their problems and live more effectively. Emotional and psychological problems are the major causes of students' 
misbehaviour such as rudeness to authority, truancy, bullying, substance abuse, pre-marital sex, telling lies and violence (Auma, 2018). Through counselling, maladaptive behaviour is altered (Mutie \& Ndambuki, 1999).

One of the principals also commented that there were guidance and counselling in their schools:

"We have a full-fledged guidance and counselling department; it is a requirement by the Ministry, it is not even a choice. The department has helped to reform some learners who were initially troublesome but now they have learnt to cope with the school environment".

The results portray a picture of school managers who are conscious of the role of guidance and counselling in school management and have therefore invested in it to ensure that schools run smoothly.

\section{School type}

School type had a significant effect on discipline. More cases were noted in both the county and extra-county schools where there were large populations. The principals also supported that school type and consequently, size was a major factor in maintaining discipline:

"The larger the school, the more the issues. As a school we have delegated the minor disciplinary cases to the class teachers; it is impossible for one teacher to deal with all the cases presented on daily basis as they are overwhelming. The cases would obviously be less if we had a leaner population."

These findings are corroborated Schwartz, Stiefel and Wiswall (2016) who aver that behaviour problems are so much greater in large schools that any possible virtue of larger size is cancelled out by the difficulties of maintaining an orderly learning environment. They maintain that in a smaller school, it is possible for an administrator to know all the students by name as well as have a face to face contact with all the teachers and support staff regularly. This personal contact creates an opportunity to have a strong grip of the personnel and the whole school at large. This yields obedience which is a strong virtue of discipline. Small schools have lower incidences of negative social behaviour than do large schools.

Shernoff, Csikszentmihaly, Schneider \& Shernoff (2014) also aver that students in small schools are involved in a greater variety of activities and that they derive more satisfaction from their participation than students in large schools. Therefore, they are less likely to participate in anti-social activities leading to a more conducive learning environment. A school teacher in a large school must exercise better planning and delegation in order to ensure that no area is neglected. Further, there is a much greater sense of belonging among students in small schools than in large ones (Chubb \& Moe, 2011). This develops a stronger sense of patriotism to the school and hence fewer indiscipline incidences compared to larger schools. Feelings of alienation from ones' school environment is both negative a thing in itself and is often found in connection with other undesirable outcome (Bracy, 2011). Alienation affects confidence, self-esteem and responsibility for self-direction. This means that smaller schools can be more relatively stable than big ones. One key feature of small schools and units is that everyone's participation is needed for clubs, teams and student government to have an adequate number of members.

\section{Effectiveness of the students' councils}

There was a general agreement that the students' councils were effective in maintaining discipline. In agreement the principals had this to say:

"As a rule we involve the learners in handling matters that directly affect them. The president and the deputy are always updated on what is happening in the school. We listen to them and in cases where their advice may not be adopted, we explain why we cannot implement their ideas. This has helped bring about relative calm in the school as the learners feel they own their school; which is a good thing."

The findings are supported by those of Kyalo, Kanori, and Njagi, (2017) who argue that effective student involvement can only be accomplished by overhauling the power structure within secondary schools so as to incorporate student participation in school governance. This will entail establishing open lines of communication between the students and the school administration, allowing students to organize themselves and elect leaders who present their grievances to the school administration, and shifting from the current situation where students are passive recipients of knowledge to active participation in the teaching-learning process (González, 2016). 
The findings further agree with the proposal by the education stakeholders who have proposed the setting up of elected Student Leadership Councils (SLCs), as opposed to appointed school prefects, as a way of enhancing school governance through student participation. Such student councils may be used to provide genuine feedback on legitimate student grievances in order to govern the school more effectively. Again, Beaudin (2015) reaffirms that where they exist in the USA and schools in Britain, student councils provide channels of communication and avenues for democratic governance in the school. Reporting similar findings, a study in Northern Nigeria showed there was a strong approval of the idea of SLCs with majority of the students seeing the SLC either as a forum where complaints could be voiced or as a means by which students would be better placed to have a say in what is going on in the school. This was despite the observation that none of the school sampled for this study had a SLC (Nyabisi, 2014).

\section{LIMITATION}

Geographical location was a limitation in that Machakos County is only one of the 47 counties in the country, therefore the sample drawn from only one county may not adequately represent the whole country. As such generalization of the study findings to the whole country should be approached with caution.

\section{RECOMMENDATIONS}

Based on the findings, the study recommended that:

(i) Secondary school administration should enhance identifying and addressing all forms of indiscipline especially vernacular speaking which was observed to be a way of including some learners while excluding others when planning acts of indiscipline.

(ii) The school administration needs to intensify guidance and counselling sessions at both the individual and group level as a means of preventing potential offenders from committing acts of indiscipline and not only for those who have already broken the school rules and regulations.

(iii) The government should ensure that there are enough teachers especially in the big schools where there is a high likelihood of cases of indiscipline.

(iv) The school administration should enhance the involvement of students' councils in the dispute resolution involving learners.

This will improve their sense of involvement in handling school matters.

\section{CONCLUSION}

The study set to find out the influence of school characteristics on the discipline of schools in Machakos County. The study concluded that noise making, sneaking out of school, rudeness/disobedience, work avoidance, vernacular speaking and bullying were all common forms of indiscipline in the schools. Vernacular speaking was especially identified as a way of including some and excluding others in the acts of indiscipline guidance and counselling helps students to maintain good behavior at all times.

School type in terms of status (national, extra-County and County) and population was also a critical factor influencing the discipline of schools. The students' councils were consulted during students' disputes resolution by the principals and teachers. The study also concluded that the learners had mixed feelings concerning the student councils in their schools with regard to whether they articulated the students' concerns to the school administration.

\section{REFERENCES}

Epstein, J. L., Sanders, M. G., Sheldon, S. B., Simon, B. S., Salinas, K. C., Jansorn, N. ～R., \& Hutchins, D. J. (2018). School, family, and community partnerships: Your handbook for action. Corwin Press.

González, C. (2011). Extending research on 'conceptions of teaching': commonalities and differences in recent investigations. Teaching in Higher Education, 16(1), 65-80

Human Rights Watch (2010). Prevalence and associated factors of physical fighting among school-going adolescents in Namibia. Annals of General Psychiatry, 6(1), 18

Jafari, S. (2016). Religion and spirituality within counselling/clinical psychology training programmes: A systematic review. British Journal of Guidance \& Counselling, 44(3), 257-267.

Jeng, A. (2011). Indiscipline in schools: The Daily Observer. Retrieved October 10 , 2012 from http://www.observer.gm>Africa $>$ Gambia. 
Kindiki, J.N., (2009). Effectiveness of communication on students' discipline in secondary schools in Kenya. Education Research Review, 4(5): 252259

Maphosa, C., \& Shumba, A. (2010). Educators' disciplinary capabilities after the banning of corporal punishment in South African schools. South African Journal of Education, 30(3).

Mbiti, D.M. (2007). Foundations of school administration. Nairobi: Oxford University Press, East African Publishers Ltd.

Mikaye, D. O. (2012). Influence of guidance and counselling on students' discipline in public secondary schools in Kabondo

Division, Kenya. A Research Project Report Submitted for the Award of the Degree of Masters of Education in Educational Administration, University of Nairobi.

Munyasia, A. (2008). Factors influencing principals' performance in the maintenance of discipline in public secondary schools in Central Division, Machakos District. Unpublished M. ED Project; University of Nairobi.

Muratha, M.M. (2013). School based factors and their effect on discipline in Secondary Schools in Kiambu East District. M. Ed Thesis, Kenyatta University

Murithi, E. W. (2010). Challenges Principals Face in Enhancing Student Discipline in Secondary School in Tigania District, Kenya, Unpublished M. ED Thesis, Chuka University.

Mutie, E. K., \& Ndambuki, P. (1999). Guidance and counseling for schools and colleges. Nairobi: Oxford University press (East Africa).

Republic of Kenya, (2001). Ministry of Education, Science and technology. Report of the Task Force on Students Discipline and Unrest in Secondary Schools (Wangai Report). Nairobi: Jomo Kenyatta Foundation.

Rukundo, B. M. (2009). Relationship between management and strikes in the Secondary schools of Uganda: a case study of Ntungamo District. Kampala: Makerere University.

UNESCO (2012). 'From School to Adulthood'? Young People's Pathways through Schooling. International Bureau of Education, Quarterly Review of Comparative Education Issue No. 128. Sadaq Bellargarde, Paris, France.

World Health Organization, \& World Health Organization. Management of Substance Abuse Unit. (2014). Global status report on alcohol and health, 2014. World Health Organization. 